平成 2 年レーザー学会学術講演会第10回年次大会

26aI4 計算機シミコレーションでる

軟 X線レ一ザ一の高効率化の研究

大阪大学レーザー核融合研究センター

高部英明, 東 博純, 加藤義章

高強度レーザ一励起 X線レーザーの方式には、衝突励起方式や輻射励起方式などの直接的励起方式と、再 結合方式のように間接的方式とがある。ここでは、物理現象が比較的簡単で、低強度レーザーでの発振が可 能な再結合方式について述べる。

再結合方式ではファイバーや図ー1に示すような平面ターグットにレーザーを集光し、急速に加熱・膨張 させ、レーザー加熱終了後断熱冷却することにより再結合時に反転分布を得る。そして、例えば炭素ターゲ ットのB a $1 \mathrm{me} \mathrm{r}$ - $\alpha$ 線の増幅を行う。シナリオは極めて単純である。

\title{
I. 増幅利得
}

輻射の輪送方程式は、その強度 $\mathrm{I}^{\vee}$ に対し

$$
\frac{1}{\mathrm{c}} \frac{\mathrm{d}}{\mathrm{d} t} \mathrm{I}^{\nu}=\eta^{\nu}-\chi^{\nu} \mathrm{I}^{\nu}
$$

と示される。ここで $\eta^{\nu}$ は自然放出率, $\chi^{\nu}$ は吸収係数。 $\chi^{\nu}$ は (長さ) $)^{-1}$ の次元でー $\chi^{\nu}$ が増幅利得 $\mathrm{G}$ なる。今、電子の始状態, 終状態を $\mathrm{n}, \mathrm{m}$ なして、その密度を $\mathrm{N} n, \mathrm{~N}_{\mathrm{m}}$ とし、又それぞれの状態数を $\mathrm{g}_{\mathrm{n}}$, $g_{\mathrm{m}}$ とすると、

$$
G=-\chi^{\nu}=\frac{h \nu}{4 \pi}\left(N_{m} B_{m n}-N_{n} B_{n m}\right)
$$

となる。ここで、B $\mathrm{mn} ， \mathrm{~B} \mathrm{~nm}$ はEinsteinのB係数で第一項が誘導放出を、第二項が純粋な吸収を示す。 ここに、関係式

$$
B_{m n}=\frac{g_{n}}{g_{m}} B_{n m} \quad, \quad B_{n m}=\frac{c^{2}}{2 h \nu^{3}} A_{n m}
$$

を代入して、結局

$$
G=\frac{c^{2}}{8 \pi \nu^{2}} A_{n m} g_{n}\left(\frac{N_{n}}{g_{n}}-\frac{N_{m}}{g_{m}}\right)
$$

となる。ここで、A $\mathrm{nm}$ はEinsteinのA係数で、

$$
A_{n m}=\frac{8 \pi^{2} e^{2} \nu^{2}}{m c^{3}} \frac{g_{m}}{g_{n}} f_{m n} \phi(\nu)
$$

$\mathrm{f}_{\mathrm{mn}}$ は吸収振動子強度。 $\phi(\nu)$ は、規格化 $(S \phi(\nu) \mathrm{d} \nu=1)$ されたスペクトル形状で、ライン幅 $\Delta \nu$ のガウス波形ではライン中心で $\phi(\nu)=(\sqrt{2 \pi} \Delta \nu)^{-1}$ となる。

Saha-Boltzman 平衡では (4) 式の（）内は、 $\left(e^{-h \nu / k T}-1\right)$ に比例し、G<0となる。従って、 いかに非平衡状態を実現し、 $N_{n}$ をより大きくし、同時に $N_{n} / g_{n} \gg N_{m} / g_{m}$ とするかが課題となる。 


\section{II. 流体運動}

$\mathrm{N}_{\mathrm{n}}, \mathrm{N}_{\mathrm{m}}$ の分布は、レーザー加熱されたプラズマ の温度・密度の時間変化で決まる。従って流体の夕゙イ ナミックスをシミュレーションする必要がある。これ にはレーザー核融合用の流体コードが流用できる。

炭素ファイバーのように軸対称近似できる場合には 一次元コードで充分である。しかし、図ー1の様な夕 ーグットでは二次元コードが必要となる。普通、レー ザー加熱流体は一流体・二温度モデルでよく記述され

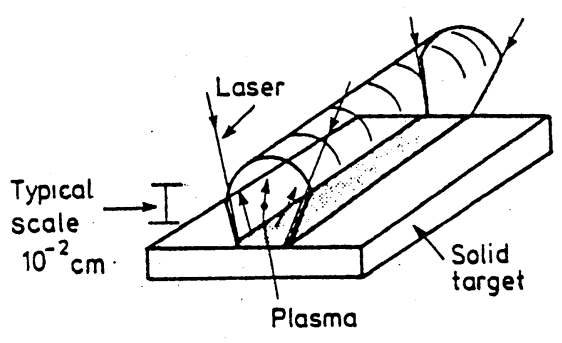

図ー1 平面ターグットヘのレーザー集光 非線形電子熱伝学が重要となる。電離状態は平均イオ ンモデルが一般に用いられる。

実際 $\mathrm{N}_{\mathrm{n}}, \mathrm{N}_{\mathrm{m}}$ 等の決定と流体方程式と はself-consistent に解かれるべきである が、ここでは流体コードの結果を一方的に 使い $\mathrm{N}_{\mathrm{n}}, \mathrm{N}_{\mathrm{m}}$ を決定していく。

図ー2に示したのは、炭素蒲膜に左右よ りレーザーを照射した時のプラズマの様子 （全体の1/4部分）を示す。上よりメッ シュ, 等密度線, 等温度線を示す。 150 p s がレーザーピークに対応。このような 流体の時間変化を使い、 $\mathrm{N}_{n}, \mathrm{~N}_{\mathrm{m}}$ の時間 変化を各部で求める。

III.レ一ト方程式

街突・輻射 (CR) モデルを基礎にしてレ 一ト方程式を解いて $\mathrm{N}_{n}, \mathrm{~N}_{\mathrm{m}}$ を求める。

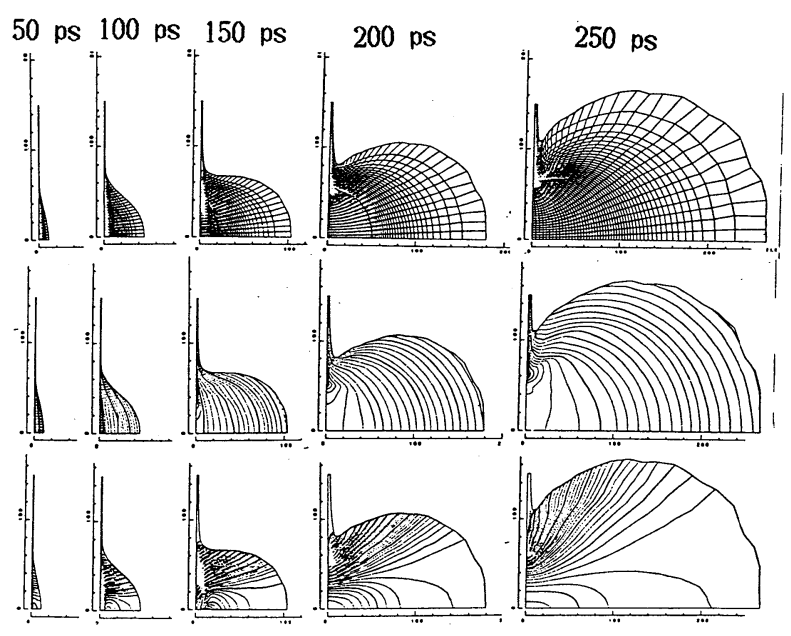

图-2＼cjkstart炭素薄膜にレーザー照射した時のブラズマの状態 上よりメッシュ, 等密度線, 等温度線

原子モデルは:Screened Hydrogenic Model (SHM)が簡便であり、よく用いられる。考え方・モデルとに大別して次の3つがある。

(1) 水素様イオンのレート方程式の準定常解。

（2）平均イオンモデルに対するレート方程式を陽に解く。

(3) いわゆるDetail Configurational Accounting を行う。

まず、（1）では $\mathrm{n}=2,3 \cdots ・ の \mathrm{~N}$ を $\mathrm{N}_{1}$ が与えられているとして、レート方程式の定常解より求 める。すると水素样原子のp-state の数 $n(p)$ は

$$
n(p)=n_{0}(p)+\widetilde{r}_{1}(p) n(1)
$$

と求まる。 $\mathrm{n}_{0}(\mathrm{p}), \widetilde{\mathrm{r}}_{1}(\mathrm{p})$ は文献 1 にテーブルとして与えられている。（6）式第二項は $\mathrm{n}(1)$ の增大 とともに、反転分布を抑える働きがある。従って $\mathrm{n}(\mathrm{p})=\mathrm{n}$ 。( $\mathrm{p}$ )として、（4）式を評価すれば利得の上 限値が近似的に求まる。これを図ー 3 - $\mathrm{a}$ に示す [2]。図中、 $z$ はレーザー物質の $z$-数で、等利得線を 示す。図ー3-aに同時に示したのは、N a F - foilに対する図ー2に相当する二次元シミュレーションの 
平成 2 年レーザー学会学術講演会第10回年次大会

結果の（ne，T e ）跡で、それぞれ初期に 表面から100,1000,3000 Å内部の样子を示す。 まず、レーザー加熱により完全電離し、レー ザーピークを過ざて冷却相に人り、利得が得 られていることがわかる。各部での電離の様 子を図ー3-bに示す。さらに空間積分した 利得の時間変化を図-3-cに示した [2]。 再結合開始とともに利得が見られる。

（2）の方法では平均イオンモデルと S H $\mathrm{M}$ を組み合わせ量子状態 $\mathrm{n}$ の平均的分布 $\mathrm{Pn}$ に対するレート方程式を解く。そして、H一

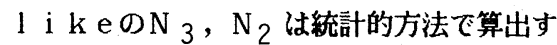
るという方法である [3]。例えば $\mathrm{n}=6$ ま で考えれば $\mathrm{P}_{1} \sim \mathrm{P}_{6}$ に対する6個のレート 方程式を解くだけでよい。この方法で 3.5 $\mu \mathrm{m}{ }^{\phi}$ の炭素ファイバーに0. 7 Joule/cm ， $25 \mathrm{p} \mathrm{s}$ パルス幅でレーザーを照射した時の 様子を図一 4 に示す。 $G=7 \mathrm{c} \mathrm{m}^{-1}$ がレーザ

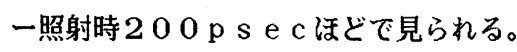

（3）の方法は、すべてのイオン価状態を 考え（2）の $z$ 倍に相当するレート方程式を 連立して解く。L L N Lで衝突励起の解析な どに用いられている。

\section{IV. 利得最適化のデザイン}

レーザー照射により完全電離する必要があ る。電子温度 $\mathrm{T}$ e $\mathrm{T} \mathrm{e} \simeq 0.2 \mathrm{E}^{\mathrm{H}} \mathrm{Z}^{2}$ ( $\left.\mathrm{E}^{\mathrm{H}}=13.6 \mathrm{e} \mathrm{V}\right)$ 程度に加熱する必要がある。 それも図ー3ーаより推測されるように密度 の高い状態で達成するほど $\mathrm{G}$ の大い冷却相 に入れる。

冷却時間が長いと、電子は基低状態に落ち ていくため、例えば（6）式でn(1) が増大 し、反転分布を得にくい。そこで急冷する必 要がある。

今、 $\mathrm{T} e$ までレーザーで加熱された後、断 熱澎張で冷却すると考えると、 T e は次の流 体式に従う。
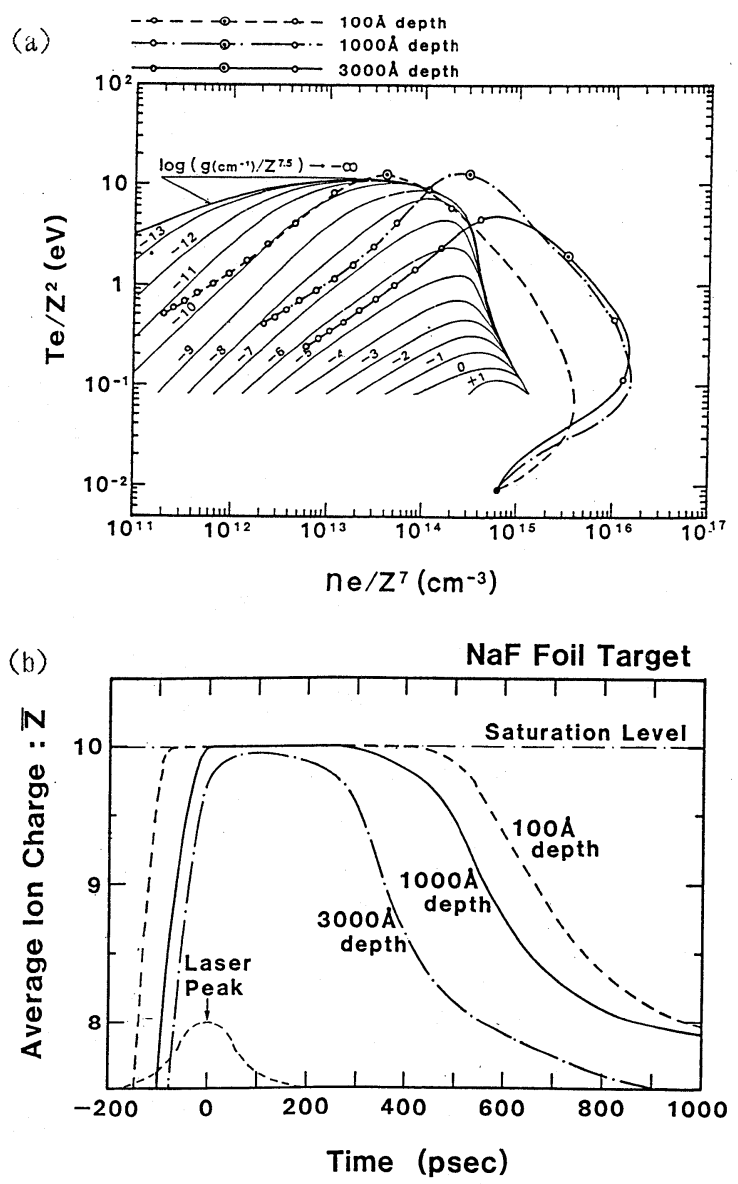

(c)

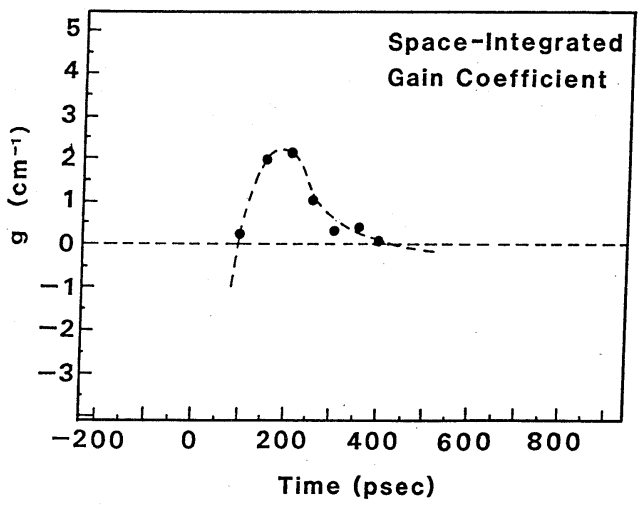

図-3 水素様イオンのレート方程式の準定常解より

得られた 2 次元シミュレーション結果

(a) 利得の上限值及び ( $\mathrm{ne}, \mathrm{Te}$ ) 跡, (b) 電離状態 の時間変化, (c) 利得の時間変化 


$$
\frac{\mathrm{dT}}{\mathrm{dt}} \mathrm{e} \simeq-\frac{2}{3} \mathrm{~T}_{\mathrm{e}} \nabla \cdot \mathrm{u}
$$

ここで図ー2の様に膨張しているとして、その広がり 角を $\theta$ とする。むし $\theta=0$ なら並行流であり、 $\nabla \cdot u$ $\approx \mathrm{C}_{\mathrm{S}} /\left(\mathrm{C}_{\mathrm{S}} \tau_{\mathrm{L}}\right)$ 程度であり、プラズマはレーザ 一パルス幅 $\tau_{\mathrm{L}}$ 程度で邻却する。ここで $\mathrm{C}_{\mathrm{S}}$ は音速。 もし $\theta=180^{\circ}$ なら二次元的に冷却し、 $\nabla \cdot u \approx u$ $/ \mathrm{r}+\partial \mathrm{u} / \partial \mathrm{r} \simeq 2 / \tau_{\mathrm{L}}$ となり、その時間スケー ルは前者の半分程度となる。従ってレーザーの短波長 化，むしくは $\theta$ を大きく取るターグットの工夫が利得 向上の指針となる。

加熱温度 $\mathrm{T} e$ は充分厚いターゲットでは $\dot{\mathrm{m}} \tau_{\mathrm{L}} \mathrm{L}_{\mathrm{H}}$ $\varepsilon_{\mathrm{p}}=\mathrm{E}$ abs $\left(\dot{\mathrm{m}}\right.$ : 質量噴出率, $\mathrm{L}_{H}:$ 図-2の加熱 幅, $\varepsilon_{p}:$ プラズマの内部エネルギーの変化量）で荒 く評価される。これにレーザープラズマのDeflagration波の関係式を用い、又、二次元コードにより $\mathrm{L}_{H}$ を与えれば $\mathrm{T} e ， \mathrm{n}_{\mathrm{e}}$ に対する簡単なスケール則が得 られる。

X線レーザー利得最通化は、レーザー爆縮のデザイ ンと同样、例えばロケット方程式に相当する様なシンプルな関係式を作り、冷却時間，冷却開始時の $\mathrm{n}_{\mathrm{e}}$ ， $\mathrm{T} \mathrm{e}$ を評洒し、指針を得ることができる。

\section{参考文献}

1. T. Fujimoto et al., Memories of Engineering, Kyoto Univ. 34 (1972).

2. 舘 用司、修士論文, 大阪大学大学院工学研究科 (1989)。

3. S. Rose and G. Pert, 私信 